\title{
ISOLATION, IDENTIFICATION AND CHARACTERIZATION OF SEED BORNE PATHOGEN ASSOCIATED WITH KENAF (HIBISCUS CANABINUS)
}

\author{
Oriowo, B.F ${ }^{1}$., Bankole, S.O ${ }^{* 2}$, Alarape, A.B ${ }^{1}$ and Adegboyega, D.A ${ }^{2}$ \\ ${ }^{1}$ Federal college of Forestry,Ibadan. \\ ${ }^{2}$ Department of Bioscience, Forestry Research Institute of Nigeria, Ibadan \\ ${ }^{3}$ Biomedicinal Research Centre, Forestry Research Institute of Nigeria,Ibadan. \\ http://doi.org/10.35410/IJAEB.2019.4429
}

\begin{abstract}
Kenaf (Hibiscus cannabinus) has been grown for thousands of years in Africa where its leaves are consumed in human and animal. Kenaf is grown in home garden for fibre, the more tender upper leaves and shoots are sometimes eaten either raw or cooked. The leaf silage is used in feeding of farm dairy animals. Seed borne pathogen are known to have negative effects on the viability of a seed and possibly on the growth and yield of a plant. Therefore this study involves Isolation, Observation and Characterization of seed borne pathogen of kenaf seeds. The seed samples used were 2QQ, S108/4, Ac-313 295, AU-245, Purple flower, Ifeken 400, AU-72 48, Ifeken 100, Cuba 108, Fanek, Tianug 1, HC 583, AU 75, G 45, V1 100, Tianug 2, Ex-Giwa, ExShika, A-60-282, and AU 7192.The seeds were isolated, Observed, Subculture, and Characterized. The microorganisms isolated were Macrophomina phaseolina, Cuvularia spp, Fusarium oxysporim, Collectotricum trucatum for fungi while the bacteria present were Cythomonas spp.
\end{abstract}

Keywords: Kenaf, Isolation, Seeds, Characterization, Microorganism.

\section{INTRODUCTION}

Kenaf (Hibiscus canabinus L) is an annual or biennial herbaceous plant native to east-central Africa. It has been grown for several thousand of years for food and fibre (Scott and Taylor, 1993).It is a common wild plant of tropical and subtropical Africa and Asia. It has been introduced to China, USSR, Thailand, South Africa, Egypt, Mexico and Cuba since the world war 11. The exact nature of origin of kenaf is not known although it thrives very well in Southern Asia.

Kenaf is a plant that is related to Okro, Cotton, Flax and Jute. It belong to the Kingdom Plantae, Order Malvates, Family, Malvaceae, Genus Hibiscus and Species H. cannabinus. The name Kenaf also implies to the fibre obtained from this plant. Kenaf has other names which include Bimli, Ambary, Ambari Hemp, Decca Hemp and Bimlipatum jute (Scott and Taylor, 1993).

The name Kenaf is of Percian origin. In India Kenaf is also known as Mesta, Palungi, Deccan hemp or Bimli jute, while in Taiwan it is called Ambari. In Egypt and Northern Africa Kenaf is known as Til, Teel or Real. In Indonesia it is Java Jute, In Brazil it is papoula de saa Fracisco. In South Africa it is Stokroos and West Africa it could be Dah, Gambo, and Rama (Fuller, 1993).

Kenaf is developed as non wood fibres crop, which grow up to $1.5-3.5 \mathrm{~m}$ tall with a woody base. The stems are about $1.2 \mathrm{~cm}$ in diameter and are often but not always branched. The leaves could be 
as long as $10-15 \mathrm{~cm}$ long, they are variable in shape with leaves near the top of the stem are shallowly lobed or unlobed lanceolate. They produce flowers, which are about $3-15 \mathrm{~cm}$ in diameter; the flowers could be white, yellow or purple in colour. When white or yellow, the centre is still dark purple. The fruit Kenaf produces is in form of a capsule which is about $2 \mathrm{~cm}$ in diameter and it contains several seeds (Mabberly, 1987).

Most insect problems with kenaf are likely to occur at seedling emergence and during young seedling growth. Cut worms, leaf miners, and other chewing/sucking insects are potential problems. Late in the season, the plant will tolerate a relative high population of leaf-chewing insects (Grower's, 1989).

The root-knot nematodes which cause galling on kenaf roots and restricts water and nutrient uptake has been a major Challenge (Sharma, 1994). One of the greatest problems affecting kenaf production is plant parasitic nematodes, particularly root-knot nematode (Meloidogyne spp). Nematodes are multicellular, microscopic, worm-like animals that feed mainly on plant root systems (Lawrence, 1994).Leaves on plants infested with nematodes yellow and fall, the plant will be stunted and if the infestation is heavy the plant may eventually die.

Root-knot nematodes can occur in any soil, but are expected to be a more serious problem on welldrained sandy soils in central Florida and somewhat less on flatwoods type soils or on phosphatic clay soils. Nematodes may be manage by a combination of crop rotation and chemical control. Telone 11. a soil fumigant, is registered for use on kenaf, but it may be too expensive to use. At the present time, none of the kenaf varieties are considered resistant to nematodes (Grower's, 1989). Use of clean planting material hot water treatment, seed treatment with suitable nematicides, rotation of crops and soil fumigation are some of the methods of control these diseases.

Kenaf is resistant to most plant diseases, but one serious disease of kenaf is Anthracnose (Wallen, 1964). Irregular and indefinite brown to black spots develop on leaves and severely affected leaves fall while the affected branches show die back condition.

On the lesions are seen small structures called acervuli bearing the conidial, which are erumpent, cushion-like masses of conidiophores. The conidia are hyaline, one-celled, ovoid to oblong. There are three important genera-Gloeosporium, Collectotrichum, and Sphaceloma. The distinction between Gloeosporium and Collectotrichum is that whereas the latter has long sterile hair or setae, Gloeosporium does not posses setate in the acevulus. However, this distinction is not clear because many Collectotrichum spp. either produce setate rarely or only under certain condition (Wallen, 1964). So this research seeks to investigate seed borne pathogen associated with Kenaf.

\section{MATERIALS AND METHODS}

\section{Collection of Samples}

Samples were collected from IAR\&T Moor Plantation Ibadan. Total of 20 lines were received from the Genetic reservation of the institute.

\section{Sterilization of Laboratory Materials.}


Glassware were washed with liquid detergent or teepol and allowed to air-dry. Petri dishes and other glassware were arranged in canisters. These canisters were sterilised in the oven (Gallenkamp Hotbox oven, Gallenkamp, UK) at $160^{\circ} \mathrm{C}$ for $1 \mathrm{hr} 30 \mathrm{mins}$. Sterile glassware was used within $24 \mathrm{hrs}$. Forceps, glass microscope slide, and scalpels were sterilised by dipping them into $70 \%$ alcohol and passing them over the flame two or three times at an angle of $45^{\circ} \mathrm{C}$ at the upper part of the flame. The inoculating needles and scalpel blades were sterilised by heating to "red hot" over a Bunsen burner. The atomiser/ sprayer and other related materials were sterilised by soaking them in $10 \%$ sodium hypochlorite $(\mathrm{NaOCl})$ for $1 \mathrm{hr}$ and later rinsed with sterile distilled water. Distilled water was sterilised using Schott Duran bottles in the autoclave at a temperature of $121^{\circ} \mathrm{C}$ and 15 pound pressure for $15 \mathrm{mins}$. The working benches and the lamina hood was sterilised by cleaning with $70 \%$ alcohol.

\section{Media Preparation}

Nutrient broth Yeast extract agar (NBY) was the medium required in this experiment. It is a dual purpose medium which enhances the growth of both bacteria and fungi. The composition is as follows: $8.0 \mathrm{~g}$ of Nutrient broth, $2 \mathrm{~g}$ of yeast extract, $2 \mathrm{~g}$ of $\mathrm{K}_{2} \mathrm{HPO}_{4}, 0.5 \mathrm{~g}$ of $\mathrm{KH}_{2} \mathrm{PO}_{4}, 2.5 \mathrm{~g}$ of glucose and $15.0 \mathrm{~g}$ was weighed in the Schott duran bottle and suspended in 1 litre of distilled water. The mixture was heated to dissolve. The mixture was then sterilised in the autoclave at $121^{\circ} \mathrm{C}, 15-$ pound pressure for 15 mins. The medium was allowed to cool to about $45^{\circ} \mathrm{C}$ under the lamina hood. $0.1 \%$ of Sodium azide was added to the medium to eliminate fungi growth. While still molten at about $45^{\circ} \mathrm{C}$, add $1 \mathrm{ml}$ of $1 \mathrm{M} \mathrm{MgSO} 0_{4}$ into the molten medium and dispensed in each $9 \mathrm{~cm}$ sterile Petri dish. The medium in the Petri dishes was left in the hood until they solidified or gel. These plates were then stored in the refrigerator at a temperature between $4^{\circ} \mathrm{C}$ until they are required. Before used, the plates were dried in a sterile oven by opening and placing them upside down at $45^{\circ} \mathrm{C}$ for $10 \mathrm{mins}$.

\section{Isolation of seed borne pathogens from Kenaf seeds samples}

Seeds were surface sterile with $10 \%$ sodium hypochlorite for 2 mins (Sutton, 1951). The seeds were then rinsed in sterile distilled water and blotted dry with sterile paper towels. 10 seeds were plated in each plate containing NBY and were incubated at $27^{\circ} \mathrm{C}$ for $24-48 \mathrm{hrs}$ for bacteria and $96 \mathrm{hrs}$ for fungi.Observation of colonies, growth and identification of the intercepted pathogens were done after $96 \mathrm{hrs}$ of incubation.Presumptive colonies of bacteria were purified by sub-culturing single colonies following procedures described. And mycelia growths for fungi were also subculture with scalpel blade on fresh medium.

\section{Bacteria}

With the aid of a sterile wire loop, a loopful of a distinct bacteria colony was transferred on a clean plate of nutrient agar. A smear of the bacteria was made on a particular location or point on the nutrient agar. Streak of lines were made from the location or point toward one edge of the plate with a sterile wire loop, which was flamed until red-hot. After flaming again another set of streak of lines were made at angle of 90 to the first set of streaked lines, the wire loop was again flamed 
to red hot and third set were made perpendicular to the second set of streaked lines. This sequential streaking, based on the principle of dilution of culture, helped to produce discrete bacterial colonies after incubation. The above procedure was repeated twice until pure isolate were obtained. The pure culture were identified using cultural and morphological characteristics as well as and by comparing the culture with the standard obtained from the Seed Health Laboratory, International Institute of Tropical Agriculture Idi Ose Ibadan

\section{Fungal Identification}

Scalpel blade was used to cut a disc from each point were there is mycelia growth of fungi. This disc was transferred on a fresh medium of Potato Dextrose Agar (PDA) and these were incubated until the pathogen sporulated. The fungi were then identified using cultural and morphological characteristics and by comparing the culture obtained from the Seed Health Laboratory, International Institute of Tropical Agriculture Idi Ose, Ibadan.

\section{Sample collection and varieties}

\begin{tabular}{|l|l|}
\hline S/N & Varieties \\
\hline 1 & 2 QQ \\
\hline 2 & $\mathrm{~S} 108 / 4$ \\
\hline 3 & $\mathrm{Ac}-313295$ \\
\hline 4 & $\mathrm{Au}-245$ \\
\hline 5 & Purple flower \\
\hline 6 & Ifeken 400 \\
\hline 7 & AU -72 48 \\
\hline 8 & Ifeken 100 \\
\hline 9 & Cuba 108 \\
\hline 10 & Fanek \\
\hline 11 & Tianug 1 \\
\hline 12 & HC 563 \\
\hline 13 & AU 75 \\
\hline 14 & G 45 \\
\hline 15 & V1 100 \\
\hline 16 & Tianung 2 \\
\hline 17 & EX - Giwa \\
\hline 18 & Ex - Shika \\
\hline 19 & A - 60- 282 \\
\hline 20 & AU 7192 \\
\hline
\end{tabular}

\section{RESULTS}


International Journal of Agriculture, Environment and Bioresearch

Vol. 4, No. 05; 2019

ISSN: $2456-8643$

The result of the experiment revealed that eight different microorganisms were found to be associated with kenaf seeds. These organisms are Fusariun oxysporum, Curvularia lunata, Aspergillus flavus, Macrophomina phaseolina, Nigrospora sp, Penicillium oxalicum, Bacillus subtilis, and Bacillus cereus (Table 4 )

Fig. 1 The morphological growth of these pathogen on PDA and Nutrient agar is show as in the plate below:

\section{Pathogens Intercepted During Isolation}
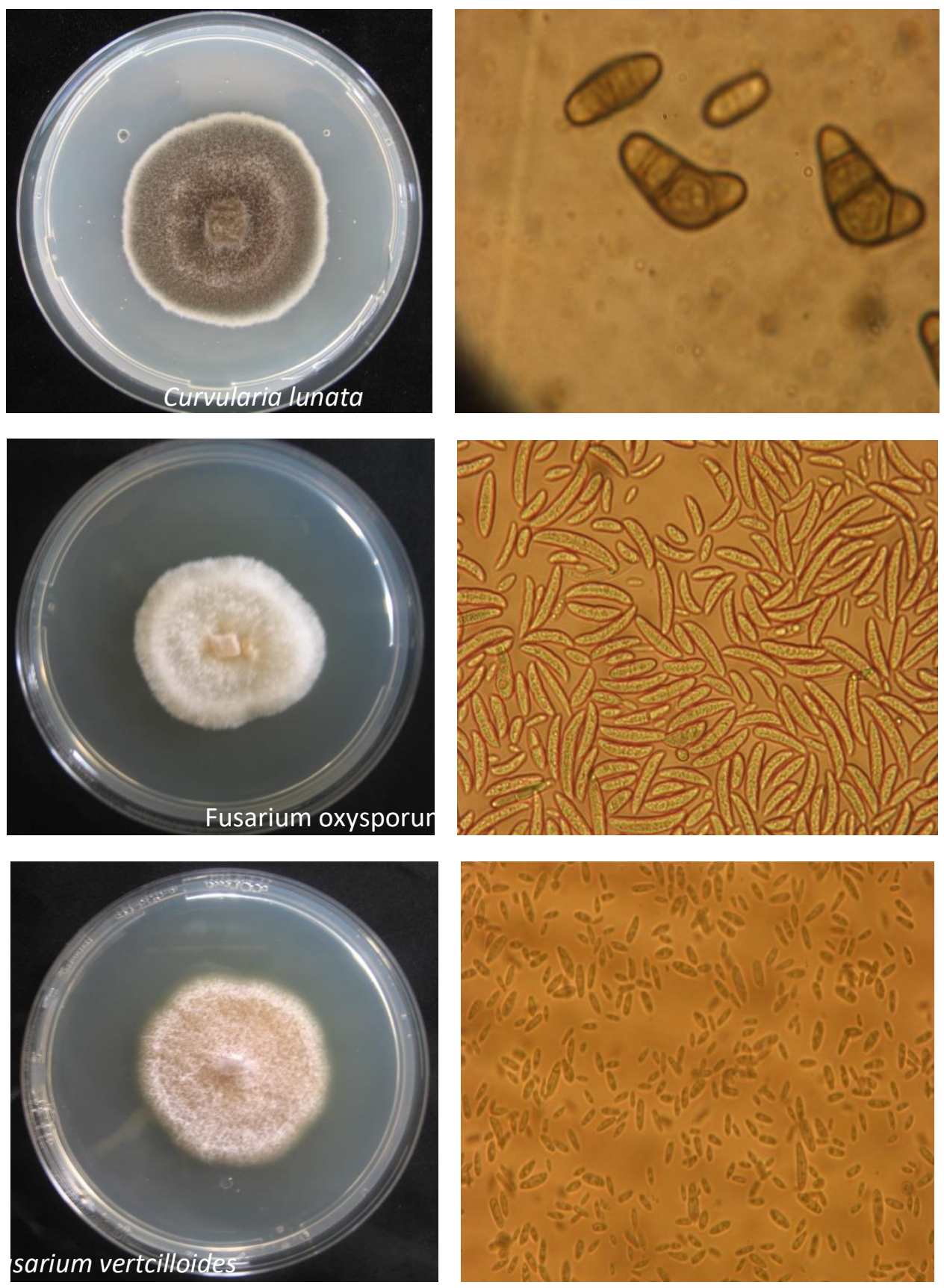
International Journal of Agriculture, Environment and Bioresearch

Vol. 4, No. 05; 2019

ISSN: $2456-8643$
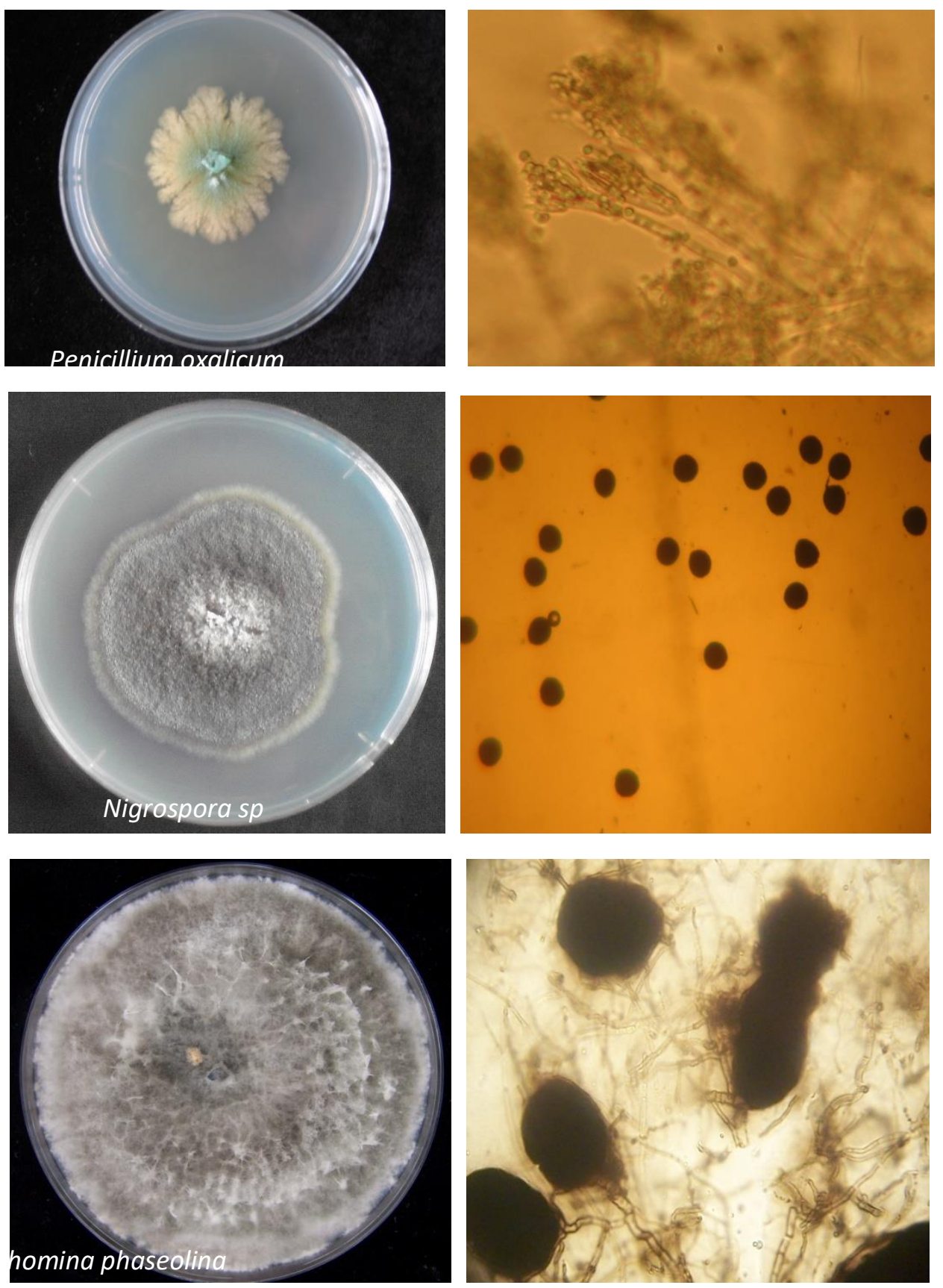

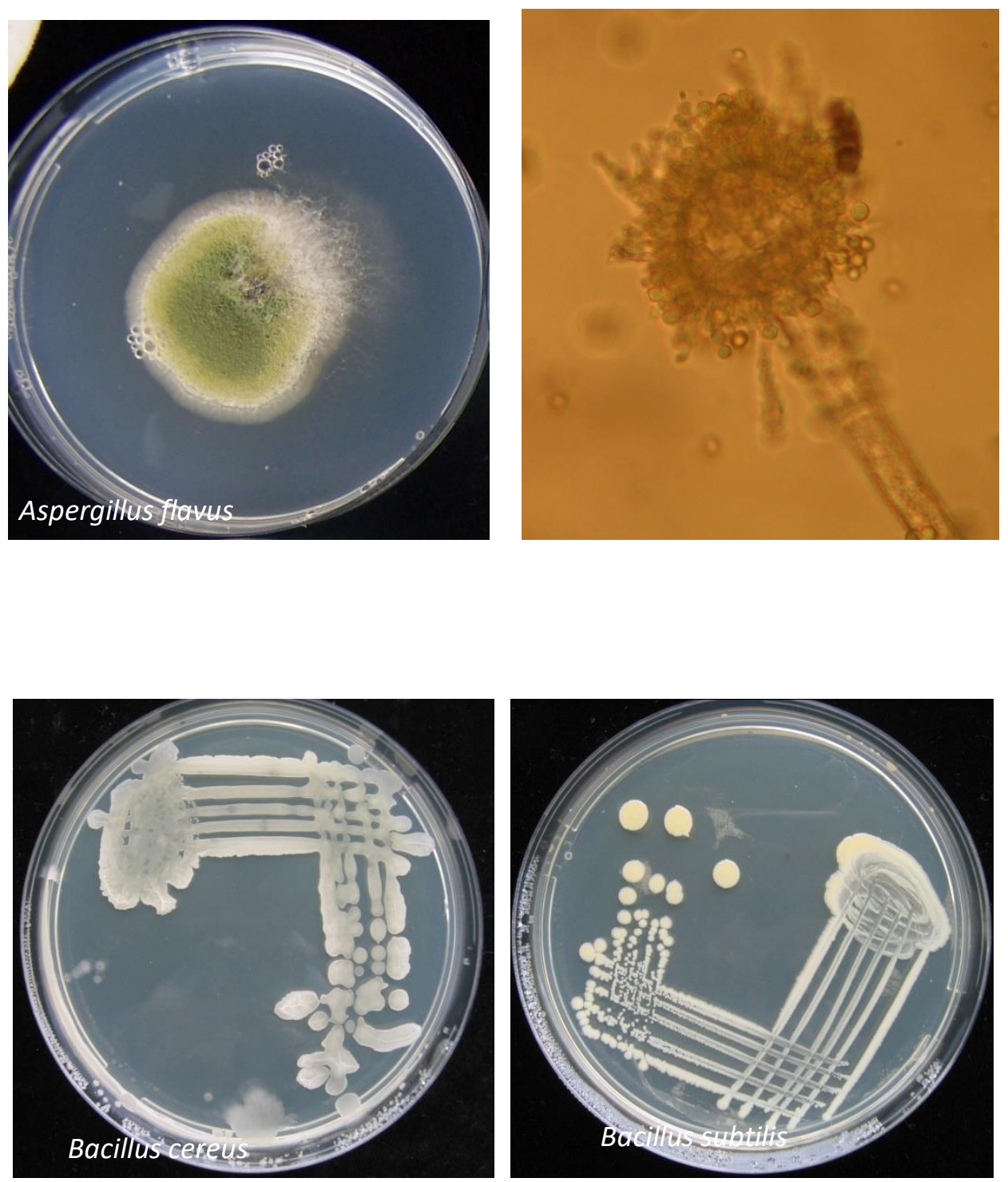

As shown in table 4, Bacillus cereus was found associated with variety S 108/4, Fanek and Au 75, while Bacillus subtilis were variety AU -72 48, AU 245, EX-GIWA. Fusarium oxysporum was found associates with variety 2QQ, HC 563, V1 100, and A-60-287. Curvularia lunata was also found associated with all the Kenaf varieties with the exception of CUBA 180, while A flavus was only found associated with varieties 2QQ and Ifeken 400. Penicilium oxalicum and Nigrospora $\mathrm{sp}$ were found associated with Ac - 313295 and Purple flower respectively (Table 4).

The rate of occurrence of Bacillus cereus(22\%) was found to be highest in variety S 108/4 followed by Fanek( $15 \%$ ) and $\mathrm{Au} 75(6 \%)$, while that of Bacillus subtilis was highest in variety Ac - 313295 (15\%), followed by that of AU 245 and S 108/4(10\%) while EX-GIWA had the least rate of occurrence, however the bacterial isolate was not isolated from the remaining kenaf varieties(Table 5). The rate of occurrence of Curvularia lunata was found to be highest in variety HC 563 and $\mathrm{Au}-245$ (90\%), followed by that of Ifeken 400 and Tianug 1 (89 and 87\% 
respectively V1 100), while the least rate occurrence was found in variety $S 108 / 4(6 \%)$. The highest rate of occurrence of M. phaseolina ( $70 \%$ ) was with variety S 108/4, followed by Tianung 2, Purple flower and Cuba 180 ( 65\% and 60\% respectively ), while the least rate of occurrence was found with variety $\mathrm{AU}-7248$ with $15 \%$ rate of occurrence(Table 5)

Table $4 \%$ incidence of micro organisms found associated with Kenaf seeds

\begin{tabular}{|c|c|c|c|c|c|c|c|c|}
\hline Varietie: & $\begin{array}{l}\text { Bacillu } \\
\text { cereus }\end{array}$ & \begin{tabular}{|l|} 
Bacillu \\
subtilis
\end{tabular} & \begin{tabular}{|l|} 
Fusariun \\
oxysporun
\end{tabular} & $\begin{array}{l}\text { Curvularic } \\
\text { lunata }\end{array}$ & $\begin{array}{l}\text { Aspergillu } \\
\text { flavus }\end{array}$ & $\begin{array}{l}\text { Macrophomin } \\
\text { phaseolina }\end{array}$ & \begin{tabular}{|l|} 
Nigrospor \\
$s p$
\end{tabular} & $\begin{array}{l}\text { Penicillium } \\
\text { oxalicum }\end{array}$ \\
\hline 2QQ & - & - & $\begin{array}{llll}+ & & & \end{array}$ & + & + & - & - & - \\
\hline S $108 / 4$ & + & - & - & + & - & + & - & - \\
\hline $\begin{array}{l}\text { Ac }-31 \\
295\end{array}$ & - & - & - & + & - & + & - & + \\
\hline $\mathrm{Au}-245$ & - & + & - & + & - & - & - & - \\
\hline $\begin{array}{l}\text { Purple } \\
\text { flower }\end{array}$ & - & - & - & + & - & + & + & - \\
\hline $\begin{array}{l}\text { Ifeken } \\
400\end{array}$ & - & - & - & + & + & - & - & - \\
\hline $\begin{array}{l}\mathrm{AU}-7 \\
48\end{array}$ & - & + & - & + & - & + & - & - \\
\hline $\begin{array}{l}\text { Ifeken } \\
100\end{array}$ & - & - & - & + & - & + & - & - \\
\hline Cuba 10 & - & - & - & - & - & + & - & - \\
\hline Fanek & + & - & - & + & - & - & - & - \\
\hline Tianug 1 & - & - & - & + & - & - & - & - \\
\hline HC 563 & - & - & + & + & - & - & - & - \\
\hline $\mathrm{Au} 75$ & + & - & - & + & - & + & - & - \\
\hline G 45 & - & - & - & + & - & + & - & - \\
\hline V1 100 & - & - & + & + & - & - & - & - \\
\hline Tianug & - & - & - & + & - & + & - & - \\
\hline Ex-Giwa & - & + & - & + & - & + & - & - \\
\hline Ex-Shika & - & - & - & + & - & + & - & - \\
\hline
\end{tabular}




\begin{tabular}{|l|l|l|l|l|l|l|l|l|}
\hline $\begin{array}{l}\text { A-60- } \\
287\end{array}$ & - & - & + & + & - & - & - & - \\
\hline $\mathrm{Au} 719$ & - & - & - & + & - & - & - & - \\
\hline
\end{tabular}

Table $5 \%$ occurrence of the micro organisms found associated with Kenaf seeds

\begin{tabular}{|c|c|c|c|c|c|c|c|c|}
\hline Variety & $\begin{array}{l}F . \\
\text { oxysporum }\end{array}$ & $\begin{array}{l}C . \\
\text { lunata }\end{array}$ & A. flavus & $\begin{array}{l}\text { M. } \\
\text { phaseolina }\end{array}$ & Nigrospora sp & P. oxalicun & B. subtili & B. Cereus \\
\hline $2 \mathrm{QQ}$ & 14 & 80 & 6 & 0 & 0 & 0 & 0 & 0 \\
\hline S $108 / 4$ & 0 & 20 & & 70 & 0 & 0 & 10 & 22 \\
\hline Ac - 313295 & 0 & 85 & 0 & 0 & 0 & 0 & 15 & 0 \\
\hline $\mathrm{Au}-245$ & 0 & 90 & 0 & 0 & 0 & 0 & 10 & 0 \\
\hline Purple flower & 0 & 30 & 0 & 65 & 5 & 0 & 0 & 0 \\
\hline Ifeken 400 & 0 & 89 & 11 & 0 & 0 & 0 & 0 & 0 \\
\hline $\mathrm{AU}-7248$ & 0 & 80 & 0 & 15 & 0 & 2 & 5 & 0 \\
\hline Ifeken 100 & 0 & 62 & 0 & 38 & 0 & 0 & 0 & 0 \\
\hline Cuba 108 & 0 & 0 & 0 & 60 & 0 & 0 & 0 & 0 \\
\hline Fanek & 0 & 75 & 0 & 0 & 0 & 0 & 0 & 15 \\
\hline Tianug 1 & 0 & 87 & 0 & 0 & 0 & 0 & 0 & 0 \\
\hline HC 563 & 5 & 90 & 0 & 0 & 0 & 0 & 0 & 0 \\
\hline AU 75 & 0 & 72 & 0 & 22 & 0 & 0 & 0 & 6 \\
\hline G 45 & 0 & 60 & 0 & 38 & 0 & 0 & 0 & 0 \\
\hline V1 100 & 22 & 78 & 0 & 0 & 0 & 0 & 0 & 0 \\
\hline Tianung 2 & 0 & 33 & 0 & 65 & 0 & 0 & 0 & 0 \\
\hline EX - Giwa & 0 & 79 & 0 & 18 & 0 & 0 & 3 & 0 \\
\hline Ex-Shika & 0 & 55 & 0 & 45 & 0 & 0 & 0 & 0 \\
\hline $\mathrm{A}-60-282$ & 25 & 45 & 0 & 0 & 0 & 0 & 0 & 0 \\
\hline AU 7192 & 0 & 80 & 0 & 0 & 0 & 0 & 0 & 0 \\
\hline
\end{tabular}

\section{DISCUSSIONS AND CONCLUSION}

Though Bacillus subtilis was intercepted on five of the Kenaf lines, the organism can neither be considered as seed borne or having potential of being seed borne because it is a gram positive bacteria and no literature has ever reported gram positive bacteria to be pathogenic nor seed borne. The presence of Bacillus cereus is also a sign of microbial contamination since the bacterium is a gram positive and is not known to induce disease condition in crops.

The result of the experiment also show the high prevalence of two fungal isolates Curvularia lunata and Macrophomina phaseolina in most of the kenaf lines or varieties used in this study. This can be interpreted that the two fungi have high tendency of being seed borne in kenaf 
Both Curvularia lunata and Macrophomina phaseolina have been implicated in seed rot, seedling diseases of many tropical crops (Amusa et al., 2002; Msikita, Baimey and James, 2007). Macrophomina phaseolina has been reported as one of the most destructive plant pathogens in the tropics and sub tropics inciting diseases in a wide number of hosts (Reuweni et al ., 1983, Singh et al ., 1990 ), while Curvularia lunata causes leaf spot in grasses and cereals. Brecht, Stiles, and Datnoff, (2007) reported the occurrence of C. lunata on Cynodon dactylon (L.). Muhammad and Kafaru (2002), also reported the isolation of Curvularia lunata from discoloured sorghum seeds obtained from the humid forest of south western Nigeria. The pathogen has also been reported to cause stem blight disease of cassava (Msikita, Baimey and James, 2007).

Fuasarium oxysporum was found associated with some kenaf lines/ varieties, the fungal isolates have been associated with seedling mortality and wilting of several crops (Shetty, 1988). Aspergillus sp was found associated with kenaf seeds, Aspergillus spp are known to have negligible effects on germination and growth of seeds (Kumar and Shetty, 1986). Some Aspergillus spp are however destructive on stored products and their presence indicative of poor storage conditions. Aspergillus flavus has been associated with the deterioration of protein content of cowpea seeds (Vijaya and Karana, 1981). The presence of Aspergillus flavus in the kenaf seed is an indication that it could be a source of mycotoxins, since A. flavus is known to produce aflatoxins in many seeds.

The presence of Nigrospora sp in the Kenaf seed lot could have resulted from contamination of the seed lots since the fungus is a known saprophyte in most crops. However, it is very much possible that the fungus could also contribute to low germination of the seed lots. Though the rate of occurrence of Penicillium oxalicum was very low, however, the fugus is a potential post harvest Pathogen causing is a post harvest disease in most crops.

The presence of these organisms on kenaf in seeds may affect the seed quality, such as germination, seedling emergency etc. as well as the quality and quantity of other product that may be associated with seeds such as oil that are extractable from seed and food reserved present in seed moreover, it is not unlikely that the infected seed might have been contaminated with mycotoxin which might be deterrent with human and animal upon consumption. All these might have negative effect on industrial uses of kenaf seed.

\section{REFERENCES}

Amusa, N.A., Florini .D., Okechukwu .R. and Akinfenwa .B.F. (2002). Pathogenicity on Cowpea of Macrophomina phaseolina Isolates from six leguminous crops in Nigeria. Journal of Pure and Applied Sciences. Vol 5 No. 1 of January -March, 2002.

Bhangoo, M.S., H. S. Tehnani, and J. Henderson. (1986). Effect of planting date, nitrogen levels, row spacing, and plant population on kenaf performance in the San Joaquin Valley, California. Agon. J. 78:600-604.

Broadway, R.(1990). Scientists find results of kenaf research encouraging. Research Highlights, Miss. Agric. and Forestry Exp.Sta.,Mississippi State, MS, 53(11):7. 
Brecht, M. O., Stiles, C. M., and Datnoff, L. E. 2007. Evaluation of pathogenicity of Bipolaris and Curvularia spp. on dwarf and ultradwarf bermudagrasses in Florida. Online. Plant Health Progress doi:10.1094/PHP-2007-0119-02-RS.

Chen, L.H. and J. Pote.(1994). In -Field separation of kenaf .pp.19-20. In M.J.Fuller, (ed.) A summary of kenaf production and Product Development Research 1989-1993.Miss.Agric. and Forestry Exp.Sta., Mississippi State, Bulletin 1011,33pgs.

Growers Handbook for kenaf Production in the Lower Rio Grande Valley of Texas, USA. (1989). Kenaf International with Rio farms, Inc., McAllen, TX, pg 21.

Katznelson, H. and M. D. Sutton (1951). "A rapid phage plaque count method for the detection of bacteria as applied to the demonstration of internal bacteria infection of seed" J. Bact., 61:689.

Killinger, G.B.(1967). Potential uses of kenaf (Hibiscus canabinus L).Proc.soil Crop Sci. Soc. FL27:4-11.

Fuller,(ed.) A Summary of Kenaf Production and Product Development Research (1989-1993) Miss. Agric. and Forestry Exp.Sta., Mississippi State, MS, Bulletin 1011,33pgs.

Kumar, V and Shetty, H.S. (1986). Dry seed examination in maize. International Journal of Tropical Plant Diseases, 4, 147-151.

Lawrence, G.W.(1994). Plant parasitic nematodes- pests of kenaf. pp. 13-14. In M.J. Fuller, ,(ed.) A Summary of Kenaf Production and Product Development Research 1989-1993 Miss. Agric. and Forestry Exp.Sta., Mississippi State, MS, Bulletin 1011,33pgs.

Luc,M., Sikora and J, Bridge (1990), Plant parasitic nematodes in subtropical and tropical Agriculture. CAB. Int. Wallingford, England.

Mayberry, D.H.1987. A new source of paper fibre. The World and I, July 1988:158163.Washinton Times Corp, Washington, DC.

Msikita, W , H. Baimey and B. D. James (2007) Severity of Curvularia Stem Blight Disease of Cassava in West Africa The American Phytopathological Society 2007, Volume 91, Number 11,Pages 1430-1435

Neill,S.W., and M.E.Kurtz. (1994). The effect of plant population on kenaf yield. pg.6. In M.J. Fuller, ,(ed.) A Summary of Kenaf Production and Product Development Research 1989-1993 Miss. Agric. and Forestry Exp.Sta., Mississippi State, MS, Bulletin 1011,33pgs.

Sharma, R. and S. D. Sharma (1994). "Seed-borne nematodes diseases and their management, "In Vistas in Seed Biology, Vol. II, T. Singh and P. C. Trivedi (Eds.), Prtintwell, Jaipur: pp 11-25.

Scott, A.W.,Jr. and C.S. Taylor. (1998). Economics of kenaf production in the Lower Rio Grande Valley of Texas. Paper presented at National Symposium on New Crops, Indianapolis, Oct. 23-26, 1988, pgs. 292-297. 
Shetty, H.S. (1988). Different types of damages in seeds caused by seed-borne fungi in pp53-62 Seed Pathology. Proceedings of the CTA Seminar held at Copenhagen, Denmark, on 20-25 June 1988. Edited by S.B. Mathur and J. Jorgensen. Technical centre for Agric. And Rural Cooperation, Wageningen, Netherland. 412pp.

Taylor, A. G. and G. E. Harman (1990). "Concepts and technologies of selected seed treatment," Ann. Rev.phytopath, 28:371.

Taylor, C.S. 1993.Kenaf- an annual crol generating a growing response from industry. kenaf International, Ltd., McAllen, TX, KI Pub. \#12, pg 4.

Thirumalachar, M. J. (1967). "Aureofungin in the control of seed borne Helminthosporium oryzae infection and seedling blight", Indian phytopath., 20:227-279.

Wallen, V. R. (1964). "Host-parasite relations and environmental influences in seed born disease", in: Microbial Behaviour, Symposia of the society for General Microbiology, Number XIV, Microbial behaviour in vivo and in vitro, pp. 187-212.

Wing, J.M 1967. Ensilabilty, acceptability and digestibility of kenaf. Feedstuffs 39(29):26.

Wood, I. M., D.J. Quick, R.A. Stiff, and N.H. Adams. 1978. Harvesting kenaf with sugarcane harvesters. World's crops, Sept /October, pgs 200-205. 